\title{
POTENTIAL SPREAD OF PESTS IN NEW ZEALAND THROUGH COMMERCIAL TRANSPORT OF NURSERY PLANTS
}

\author{
M.R. MCNEILL ${ }^{1}$, C.B. PHILLIPS ${ }^{1}$, N.L. BELL ${ }^{2}$ and J.R. PROFFITT ${ }^{1}$ \\ ${ }^{1}$ AgResearch, PO Box 60, Gerald Street, Lincoln, New Zealand \\ ${ }^{2}$ AgResearch, Ruakura Research Centre, Private Bag 3123, Hamilton, \\ New Zealand
}

Corresponding author: mark.mcneill@agresearch.co.nz

\begin{abstract}
This study assessed the potential for plant pests to be transported within New Zealand in association with shipments of plants among commercial nurseries in North and South Islands. Searches of soil and litter sampled from three deliveries of nursery plants to Christchurch indicated there is enormous potential to vector plant pests on this pathway. A diversity of nematodes, seeds and arthropods was recovered, including Trichodorid and Xiphinema nematodes, which can vector some plant viruses and currently have limited distributions in New Zealand. This small survey showed that transport of nursery plants must be an important pathway for the dispersal of a wide range of organisms within New Zealand. Not only is there a direct threat to the nursery plant industry from the activity of some pest species but also there is the obvious potential to spread pathogens and arthropod pests into the wider environment.
\end{abstract}

Keywords: biosecurity, pest dispersal, human-assisted pest movement, nematode pests, insect spread.

\section{INTRODUCTION}

About 40 unwanted, new organisms were detected in New Zealand in 2003 and this number has been steadily increasing each year since 1990 (Wilson et al. 2004). The accidental arrival and establishment of new pests into New Zealand can have significant financial and social costs both in terms of eradication (e.g. painted apple moth, Teia anartoides Walker, Lepidoptera: Lymantriidae) and phytosanitary controls placed on New Zealand exports, as is the case with the newly discovered plant disease Phytophthora kernoviae Brasier, Beales, and Kirk (AQIS 2006). There are also ecological costs associated with the establishment of new organisms, such as with didymo (Didymosphenia geminata (Lyngbye) M. Schmidt).

For these reasons, MAF Biosecurity aims to prevent foreign, unwanted organisms from becoming established in New Zealand. Attempts to eradicate newly discovered, unwanted organisms are undertaken where the potential risk from the organism is high, a successful outcome is plausible and the intended actions are acceptable to stakeholders (Stephenson et al. 2003; Wilson et al. 2004). Containing the spread of the targeted pest throughout the campaign is fundamental to eradication success (Stephenson et al. 2003). In cases where eradication is not possible, 'slow to spread' measures may be implemented to delay distribution of the pest to uninfested regions (e.g. varroa bee mite). Although it is generally difficult to limit pests' natural dispersal (e.g. aerial dispersal), it is possible to influence the extent to which humans unintentionally assist them to spread.

Nematodes in particular have very limited dispersal abilities so their spread is largely via human or animal movement (Boag 1985; Jikumaru \& Togashi 2003). For plant parasitic nematodes, dispersal is restricted largely to movement of soil, although some 
genera (e.g. Heterodera, Paratylenchus and Ditylenchus) have life stages able to survive in dry soil. Transportation of plants therefore has obvious potential to assist pests to spread. The survey described here assessed movements of insects, nematodes and seeds in association with the commercial carriage of nursery plants within New Zealand.

\section{METHODS AND MATERIALS}

On three separate occasions, 25 June 2004, 01 September 2004 and 8 April 2005, truck and trailer units delivering plants to South Island nurseries were sampled for invertebrates and weeds. The consignments included flowering shrubs and bagged or bare-rooted trees originating from nurseries in several North Island locations, including Hamilton, Te Awamutu, New Plymouth and Palmerston North. Samples were taken from material being delivered to Christchurch nurseries, but the trucks were also delivering plants to a wide range of other South Island locations. Litter was sampled from the top of plant containers along with litter, potting mix and soil taken from the decks of the truck and trailer unit. Sampling was carried out by hand or by using a blower-vac with a net fitted to the inlet to catch the debris. No potting mix was sampled from within the plant containers.

\section{Arthropods}

On all three sampling occasions, arthropods were extracted from litter and soil using the Berlesse-Tullgren funnel technique, which relies on heat from a light bulb to drive living organisms from the litter into a collecting vial containing $70 \%$ ethanol. Arthropods were categorised into order, family and life stage (e.g. larva, adult).

\section{Nematodes}

From the June 2004 sample, over $30 \mathrm{~kg}$ of soil, litter and potting mix was collected. Therefore, ca $13 \mathrm{~kg}$ of soil was sent to Ruakura, where 11 subsamples of $75 \mathrm{~g}$ were taken and nematodes extracted over $72 \mathrm{~h}$, using the tray method described by Bell \& Watson (2001). Briefly, soil was placed on a layer of tissue paper overlaying fine and coarse meshes contained within a plastic photographic tray. The soil was saturated by adding $500 \mathrm{ml}$ of tap water into the tray, and trays were maintained at room temperature for the duration of the extraction. Nematodes were observed at $20-80 \times$ magnification and plant feeding species were identified to genus.

The possibility of transfer and establishment of nematodes from transported bare rooted trees to a Christchurch nursery was investigated further. Here, bare rooted trees received from the North Island are dug into rotted sawdust where they remain prior to delivery to clients in the Canterbury region. Therefore, in April 2005 the sawdust into which the trees were temporarily placed, soil in an adjacent waste area, soil under native shrubs and potting mix around Betula pendula Roth (European white birch) was sampled using a $25 \mathrm{~mm}$ corer to a depth of $100 \mathrm{~mm}$. Six samples were taken from each location, transferred to plastic bags and sent to AgResearch, Ruakura, for extraction.

Seeds

From the June 2004 consignment, approximately $2.5 \mathrm{~kg}$ of soil was dried for $16 \mathrm{~h}$ at $60^{\circ} \mathrm{C}$. The sample was coarse sieved to remove leaf litter and three lots of $500 \mathrm{~g}$ of soil was placed in plastic bags. The samples were forwarded to the National Seed Laboratory (AgriQuality Limited) where any seeds found in the soil were identified.

\section{Arthropod species}

\section{RESULTS AND DISCUSSION}

On all three sampling occasions, large numbers of a wide range of arthropods were recovered, with Collembola and Acari being the most abundant (Table 1). Arthropods were found in their nymphal, larval, pupal and adult stages. The diversity of arthropods shown in Table 1 is probably an underestimate of that associated with the consignments of nursery stock because plant foliage was not directly sampled. Many of the families represented in the samples contain species that are well known as pests (e.g. springtails, aphids, mites, scales, thrips and weevils). It seems possible that some very important pests which still have restricted distributions in New Zealand might frequently be 
associated with nursery stock. For example, an adult Listronotus bonariensis (Coleoptera: Curculionidae) was recovered from the litter in one of the samples and it is conceivable that a highly mobile weevil, such as Sitona lepidus Gyllenhal (Coleoptera: Curculionidae), which has only recently been found in the South Island, could occur in clovers growing as weeds in nursery plant containers. Similarly, bees have been seen visiting flowering plants placed on the deck of the covered truck (G. Hayman, pers. comm.), which suggests there is a risk that the distribution of varroa bee mite (Varroa jacobsoni Oudemans) could be extended from the North Island to the South Island via this pathway.

TABLE 1: The order, family and life stage of arthropods extracted from litter and soil collected on three occasions from a trailer unit transporting plant material from North to South Island nurseries.

\begin{tabular}{|c|c|c|}
\hline Order & Family & Stage \\
\hline Acari (mites) & Orbatidae, Phytoseiidae, others & Adults \\
\hline Araneae (spiders) & Salticidae, others & Adults \\
\hline Collembola (springtails) & $\begin{array}{l}\text { Isotomidae, Sminthuridae, } \\
\text { Entomobryidae }\end{array}$ & Larvae, adults \\
\hline Diplopoda & Millipedes & Adults \\
\hline Coleoptera & $\begin{array}{l}\text { Staphylinidae (rove beetles), } \\
\text { Curculionidae (weevils), others }\end{array}$ & Larvae, adults \\
\hline Diptera & $\begin{array}{l}\text { Sciaridae (fungus gnats), Psychodidae } \\
\text { (sand flies), Empididae, others }\end{array}$ & $\begin{array}{l}\text { Larvae, pupae } \\
\text { adults }\end{array}$ \\
\hline Hemiptera (sucking bugs) & Aphididae (aphids), Coccidae (scales) & Larvae, adults \\
\hline Hymenoptera & $\begin{array}{l}\text { Braconidae, Ichneumonidae (parasitoid } \\
\text { wasps), Formicidae (ants) }\end{array}$ & Adults \\
\hline Lepidoptera & Moths & Larvae, adults \\
\hline Pscoptera & barklice & Larvae, adults \\
\hline Thysanoptera & Thripidae (thrips) & Larvae \\
\hline
\end{tabular}

\section{Nematodes}

Trichodorids (probably Paratrichodorus) and Pratylenchus were the most commonly observed nematodes (Table 2). In terms of damage potential, particularly to woody plants, the Xiphinema nematodes are the most problematic as they not only cause direct feeding damage to plant roots (including root swelling in some cases) but they are also vectors of plant viruses (e.g. Jones et al. 1995). There are currently six species of Xiphinema reported from New Zealand (D. Sturhan, pers. comm.), with three found in the South Island. Two occur only in the Nelson area (X. krugi and X. radicicola), and another (X. diversicaudatum) is reported from south of Nelson (Sturhan et al. 1997).

TABLE 2: Plant parasitic nematode genera observed from soil removed from truck transport and an indication of their abundance and frequency of occurrence in the 11 subsamples.

\begin{tabular}{lcccc}
\hline $\begin{array}{l}\text { Nematode } \\
\text { family/genus }\end{array}$ & $\begin{array}{c}\text { Likelihood of } \\
\text { establishment }\end{array}$ & $\begin{array}{c}\text { Damage } \\
\text { potential }\end{array}$ & $\begin{array}{c}\text { No. of } \\
\text { subsamples } \\
\text { where present }\end{array}$ & $\begin{array}{c}\text { Abundance } \\
\text { per subsample }\end{array}$ \\
\hline Trichodoridae & Low & High & 11 & $\begin{array}{c}\text { Common to abundant } \\
\text { Pratylenchus }\end{array}$ \\
High & Moderate & 11 & Rare to abundant \\
Xiphinema & High & Low & 11 & Rare \\
Paratylenchus & Medium & High & 7 & Rare \\
\hline
\end{tabular}


Trichodorid nematodes can also vector some plant viruses (e.g. Brown et al. 1989) and are probably somewhat more widespread than Xiphinema, although still with a limited South Island distribution in many cases. All three of the remaining plant parasitic genera have nationwide distributions.

Despite the presence of economically important nematodes in the soil taken from the deck of the truck, sampling at the nursery did not find Trichodorid or Xiphinema nematodes. The waste area contained Pratylenchus, Paratylenchus and Heterodera (cyst) nematodes with Heterodera also found in one of the sawdust samples. This suggests that while the nematodes occur in the soil around transported bare rooted trees and are dislodged during transport, either they are not present in the soil adhering to the roots, or they do not survive transfer into the sawdust at the nursery. The plant feeders found in the waste area are likely to be associated with weeds growing there.

Seeds

Seeds from 30 different plant species were found, with Amaranthus, Cardamine and Poa being the most common species (Table 3), but $43 \%$ of the species were represented by a single seed. While none represent significant new weed threats to the South Island, the results demonstrated the potential for inadvertent transfer of economically important weed species (e.g. kikuyu grass), to be unintentionally spread in New Zealand.

TABLE 3: Plant species and number of seeds recovered from $2.5 \mathrm{~kg}$ soil removed on 25 June 2004 from trailer unit transporting plant material from North to South Island nurseries.

\begin{tabular}{llr}
\hline Common name & Scientific name & Total seeds \\
\hline Amaranth & Amaranthus sp. & 103 \\
Annual mouse-ear chickweed & Cerastium glomeratum & 1 \\
Bittercress & Cardamine sp. & 22 \\
Black nightshade & Solanum nigrum & 6 \\
Catsear & Hypochaeris radicata & 1 \\
Clovers & Trifolium (two spp.) & 15 \\
Fathen & Chenopodium album & 2 \\
Grass species & Nine species & 38 \\
Hairy birdsfoot trefoil & Lotus suaveolens & 1 \\
Hawksbeard & Crepis capillaris & 1 \\
Hedge mustard & Sisymbrium officinale & 1 \\
Hydrocotyle & Hydrocotyle sp. & 1 \\
Oxalis & Oxalis sp. & 8 \\
Plantain & Plantago (two spp.) & 7 \\
Purslane & Portulaca oleracea & 1 \\
Wireweed & Polygonum aviculare & 2 \\
Scarlet pimpernel & Anagallis arvensis & 1 \\
Twin cress & Coronopus didymus & 11 \\
Violet & Viola sp. & 1 \\
Vulpia hair grass & Vulpia bromoides & 3 \\
\hline
\end{tabular}

This research has shown that transportation of plants almost certainly provides a significant, unintentional, human-assisted means of spread of many pests within New Zealand. While none of the insects, acarids or weeds found in these samples appears to be unique to the South Island, the Trichodorid and Xiphinema nematodes are more restricted in their distribution and are known vectors of plant viruses. The geographical distribution of nurseries visited by the commercial road transport company involved in this study range from Whangarei to Invercargill, New Plymouth to Gisborne and West Coast to Christchurch. Moreover, the service runs on a weekly basis all year round 
providing ample opportunity for pests to be spread rapidly throughout the country. The range and volume of plant material being transported around New Zealand, along with the diversity of often cryptic organisms associated with it, makes it difficult to envisage practical management solutions. Nevertheless, the nursery plant industry would directly benefit from reductions in the rate of spread of pathogens and arthropod pests in New Zealand. One approach to reducing the risk would perhaps be to encourage the adoption of an industry-wide plant hygiene standard.

However, the movement of potential pests is clearly not restricted to commercial nurseries and numerous other plant-based industries, as well as amateur gardeners, must also contribute to this issue. For these reasons, the development of effective strategies to reduce internal movements of pests in association with transportation of nursery plants represents a large and complex challenge, which will require commitment from plant protection scientists, the nursery industry, the public and probably also government agencies such as the Ministry of Agriculture and Forestry.

\section{ACKNOWLEDGEMENTS}

We thank Grant Hayman (Headford Propagators), Murray Mannall (Southern Woods Nursery) and several other nurseries for their assistance and support in this project. We are also grateful to the National Seed Laboratory (AgriQuality Limited) for the seed identifications. This research was funded by FRST contract C10X0317, 'Improved Biosecurity'.

\section{REFERENCES}

AQIS 2006. ICON Alerts PQA0474. www.aqis.gov.au/icon32/asp/ex_alertscontent.asp (accessed 7 April 2006).

Bell NL, Watson RN 2001. Optimising the Whitehead and Hemming tray method to extract plant parasitic and other nematodes from two soils under pasture. Nematology 3: 179-185.

Boag B 1985. The localised spread of virus-vector nematodes adhering to farm machinery. Nematologica 31: 234-235.

Brown DJF, Ploeg AT, Robinson DJ 1989. A review of reported associations between Trichodorus and Paratrichodorus species (Nematoda: Trichodoridae) and tobraviruses with a description of laboratory methods for examining virus transmission by trichodorids. Revue de Nematologie 12: 235-241.

Jikumaru S, Togashi K 2003. Boarding abilities of Bursaphelenchus mucronatus and B. xylophilus (Nematoda: Aphelenchoididae) on Monochamus alternatus (Coleoptera: Cerambycidae). Nematology 5: 843-849.

Jones AT, Brown DJF, Halbrendt JM, Vrain TC, Robbins RT, Ramsdell DC, Barba M 1995. The transmission of three nepoviruses by populations of four Xiphinema americanum-group species. Acta Horticulturae 385: 105-109.

Stephenson BP, Gill GSC, Randall JL, Wilson JA 2003. Biosecurity approaches to surveillance and response for new plant pest species. New Zealand Plant Protection 56: 5-9.

Sturhan D, Wouts WM, Grandison GS, Barber CJ 1997. Nematode vectors of plant viruses in New Zealand. New Zealand Journal of Zoology 24: 309-322.

Wilson JA, Stephenson BP, Gill GSC, Randall JL, Vieglais CC 2004. Principles of response to detections of new plant pest species and the effectiveness of surveillance. New Zealand Plant Protection 57: 156-160. 